International Journal of Advanced Trends in Computer Science and Engineering

Available Online at http://www.warse.org/IJATCSE/static/pdf/file/ijatcse3181.62019.pdf

https://doi.org/10.30534/ijatcse/2019/3181.62019

\title{
Analysis of Adaptive Perturb and Observe-Fuzzy Logic Control Maximum Power Point Tracking for Photovoltaic Boost DC-DC Converter
}

\author{
Muhammad Ammirrul Atiqi Mohd Zainuri ${ }^{1}$, Ezril Aidil Azari ${ }^{2}$, Ahmad Asrul Ibrahim ${ }^{3}$, afida ayob ${ }^{4}$, \\ Yushaizad Yusof ${ }^{5}$, Mohd Amran Mohd Radzi ${ }^{6}$ \\ ${ }^{1,3,4,5}$ Centre for Integrated Systems Engineering and Advanced Technologies (Integra), Department of Electrical, \\ Electronic and Systems Engineering, Universiti Kebangsaan Malaysia (UKM), Malaysia, \\ ammirrulatiqi@ukm.edu.my'; ahmadasrul@ukm.edu.my ${ }^{3}$; afida.ayob@ukm.edu.my ${ }^{4}$; yushaizad@ukm.edu.my ${ }^{5}$ \\ ${ }^{2}$ School of Electrical and Electronic Engineering, Universiti Sains Malaysia, Malaysia, aedrill88@ gmail.com \\ ${ }^{6}$ Department of Electrical and Electronic Engineering, Universiti Putra Malaysia, Malaysia, \\ amranmr@upm.edu.my
}

\begin{abstract}
This paper presents the modelling and simulation of MPPT algorithm which used the Adaptive perturb and observe-fuzzy logic control method with different membership functions. This study will investigate which levels of membership functions has the highest performance in the MPPT algorithm itself. MATLAB/Simulink was used for simulation studies. The boost dc-dc converter was built in all the simulation where the pulse width modulation (PWM) is regulated according to the duty cycle from the MPPT algorithm. The complete standalone PV system consists of perturb and observe (P\&O), Adaptive P\&O-FLC with 4,5 and 7 membership functions. The different membership functions were used to test and investigate the comparison and effectiveness of the proposed MPPT algorithm in a PV system. Adaptive P\&O-FLC with 5 membership functions show the best performances as compare to the Adaptive P\&O-FLC with 4 membership functions and Adaptive $\mathrm{P} \& \mathrm{O}-\mathrm{FLC}$ with 7 membership functions especially in term of overshoot and time response.
\end{abstract}

Key words : Photovoltaic, Maximum Power Point Tracking, Adaptive Perturb \& Observe -Fuzzy logic control, Boost dc-dc converter, Matlab/Simulink, Artificial Intelligent.

\section{INTRODUCTION}

Malaysia has the climate of hot and humid where to the North of Malaysia there is subequatorial monsoon. It usually experiences heavy rain and thunderstorms especially in the afternoon until night. This monsoon transition phase causes the regional areas in the country to experience cloudy because of heavy rain and thus affect the irradiance for the Photovoltaic cell [1-4]. This phenomenon makes the PV energy becoming a very attractive alternative resource due to the energy crisis from pollution, global warming effect and the unpredictable weather [5-7]. However, PV has major disadvantages of high cost and low efficiency conversion compared to other sources like wind and biomass [4]. The output characteristic of photovoltaic array is nonlinear because of the instability of photovoltaic (PV) energy. The output voltage and current of the PV array will change depends on irradiance and temperature. An algorithm called Maximum power point tracking (MPPT) is used widely in PV system to compensate the nonlinearlity of PV output power and to maintain the maximum power output according to the effects of difference of irradiance and temperature.

Perturb and observe $(\mathrm{P} \& \mathrm{O})$ algorithm is the most common and popular MPPT algorithm because of its simplicity and easy to be implemented [8-11]. However, it has a few drawbacks that effects PV system such as follows:

- Force the operating point to operate near MPP, oscillations around the MPP appear in steady state and this produce the power loss in the system [12].

- Small step size contributes to the oscillation that negligible and slower time response [13].

- Fail to give accurate MPP under the rapid changing environment conditions [14].

- Large perturb value cause higher oscillation and smaller perturb value causes slower time response [15].

Artificial intelligence (AI) MPPT are now more commonly used to replace the conventional MPPT algorithm even though both usages are similar in term of increasing the efficiency of the PV module. Vastly number of developed AI are used in MPPT such as fuzzy logic control (FLC), artificial neural network, evolutionary algorithms, stimulated annealing and a combination of different AI like FLC and ANN that are called neuro-fuzzy [16]. AI have a lot of advantages in terms of good tracking efficiency and fast convergence speed. FLC is the simplest and practical to be implemented in the MPPT which also has better performance compared to the conventional $\mathrm{P} \& \mathrm{O}$ algorithm. The use of the FLC MPPT algorithm still has drawbacks where it can't locate the MPP adequately. The input and error change calculation process cause the MPPT's response time and accuracy to track the MPP. Most the MPPT method did not 
consider the noise factor especially under the low irradiation which causes high oscillations to occur. Thus, the combination of both MPPT is developed to overcome each of the MPPT algorithm's drawbacks. This study uses the combination of P\&O and FLC to create a single algorithm where it has the advantages of being simple and quick, it can also respond well to noises [17].

This paper works on the optimization of the Adaptive P\&O and FLC which to compare the steady-state and dynamic performances with different conditions of irradiance and different membership functions. The membership function of fuzzy in this work include from 4 membership functions (Negative Big, Negative Small, Positive Small and Positive Big), 5 membership functions (Negative, Zero, Positive Small, Positive and Positive Big) and 7 membership functions (Negative Big, Negative, Negative Small, Zero, Positive Small, Positive and Positive Big). This work mainly focusses on the low irradiation which it has the significant effect on the MPPT algorithm. In order to further clarify this research, part 2 discusses the concept of boosting the PV system's dc-dc converter and accompanied by analysis of MPPT algorithms in terms of their concept and modification made in part 3. the findings will be discussed in part 4 including the simulation works involve steady state and dynamic operation, respectively. Finally, part 5 summarizes the research findings.

\section{BOOST DC-DC CONVERTER}

Step up dc-dc converter or boost converter is widely used in the PV system because of its lower current rating for power switches and gate drivers, the structure of boost converter which has free-wheeling diode can avoid reverse current, better dynamic performance and cheaper to implement compared to the buck and buck-boost converters. The topology of boost dc-dc converter consists of power electronic switch, capacitor, diode, inductor and load. The working principle of the boost converter is it regulates the output voltage by adjusting the duty cycle through power electronic switches based on the frequencies and duty ratio. Boost converter is needed to step-up the dc voltage from the output of the PV module. The value of the inductor used is $100 \mu \mathrm{H}$, capacitor is about $400 \mu \mathrm{F}$ and the resistive load is $50 \Omega$. The output for the boost dc-dc converter was $25 \mathrm{~V}$, delivering $34 \mathrm{~V}$ with a PWM duty cycle of about $24 \%$.

\section{MAXIMUM POWER POINT TRACKING ALGORITHMS}

Perturb and observe (P\&O) MPPT is the commonly used conventional MPPT as it is less complex, basic, and low-cost. $\mathrm{P} \& \mathrm{O}$ operates by perturbing the voltage point and observing the power varied to give changes to the voltage reference. This method also depends largely on the step size of the algorithm as the step size large, it will have faster response time and oscillation near MPP will be large [13]. This method can give moderate accuracy and operating point oscillates around MPP. The oscillation, however, can be reduced by reducing the perturbation step size, but it will affect the MPPT to become slower. P\&O and hill climbing (HC) are different method, but both also has the same working principle. The P\&O basically used perturbation in terminal voltage while the $\mathrm{HC}$ used perturbation in duty cycle [18]. Figure. 1 Illustrates a conventional MPPT P\&O flowchart.

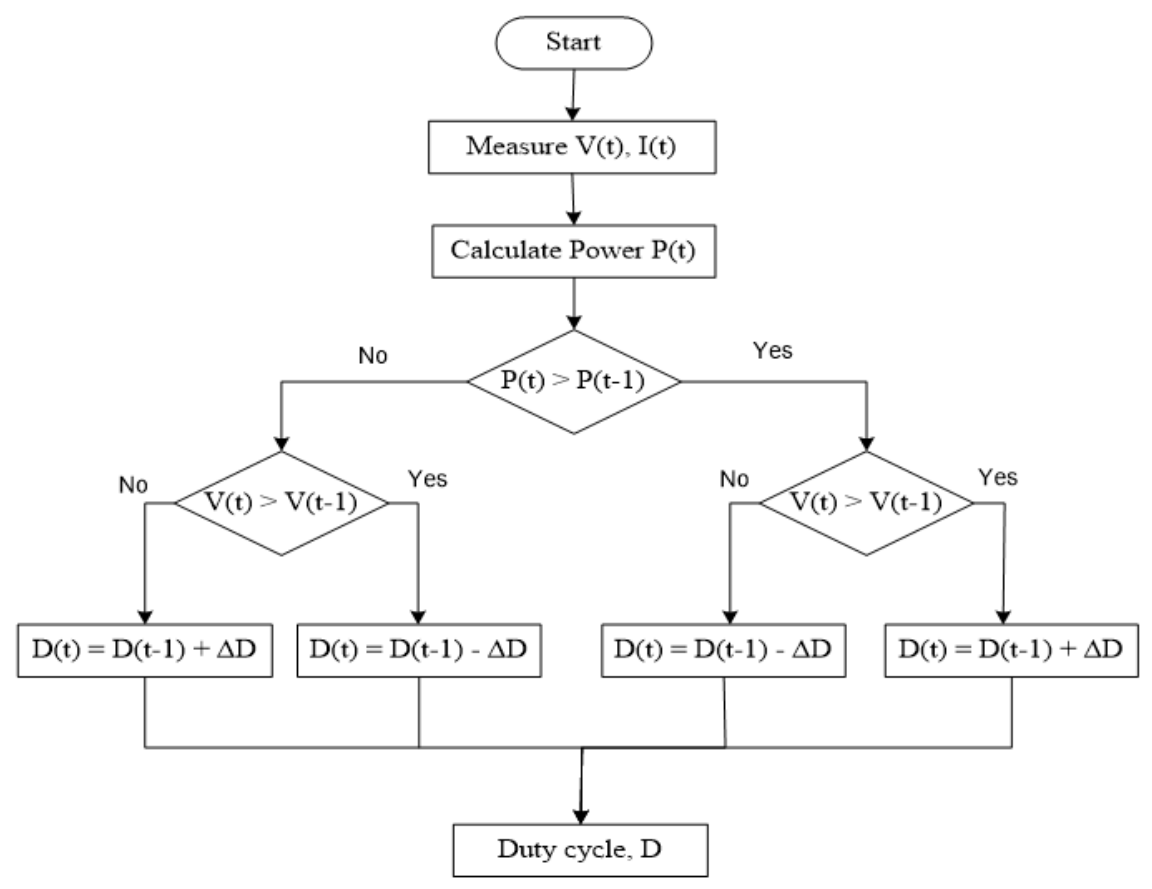

Figure 1: $\mathrm{P} \& \mathrm{O}$ algorithm flowchart 
Fuzzy logic control (FLC) can be classified into three stages, fuzzification, rule evaluation and defuzzification shown in the Figure. 2. Fuzzy inference system (FIS) has two methods, Mamdani and Sugeno. The major difference of these two types of FIS is the output fuzzy sets produced by fuzzy inputs. The Mamdani type uses the defuzzification while the Sugeno type uses weighted average to produce the output fuzzy. Thus, the membership function of Sugeno type are linear or constant while the Mamdani type output membership function is fuzzy sets [19, 20]. In MPPT application, the Mamdani type is commonly used for interference, max-min as aggregation and Center Of Area (COA) as defuzzification [13, 21]. Figure. 2 shows the block diagram of conventional FLC.

The combination of Adaptive P\&O-FLC specifically designed to overcome each of the methods disadvantages and come out with more efficiency than the conventional method. P\&O only involve in the perturbation of the duty cycle by comparing the power and voltage from the previous values. While the FLC uses the error and change of error which involve in complex calculation process especially in division calculation. Adaptive P\&O-FLC MPPT uses inputs of differential power, $\Delta \mathrm{P}$ and differential of voltage, $\Delta \mathrm{V}$ which is the same in the $\mathrm{P} \& \mathrm{O}$ algorithm. The $\Delta \mathrm{P}$ means the difference in the previous power with the present power and $\Delta \mathrm{V}$ means the difference in the previous voltage with the present voltage. In this process of the Adaptive P\&O-FLC MPPT, the inputs are replaced with the $\mathrm{P} \& \mathrm{O}$ which will produced a better performance while the output is the sum of the step size of the duty cycle, $\Delta \mathrm{D}$ and initial duty cycle which is different from the conventional MPPT methods that uses duty cycle directly. The $\Delta \mathrm{D}$ means the difference in the present duty cycle and the previous duty cycle. Therefore, the new inputs produced by the P\&O MPPT algorithm were used in the inputs for FLC MPPT algorithm with the membership function variable of 4, 5 and 7. Figure. 3 shows the flowchart of the Adaptive P\&O-FLC algorithm. The inputs of the algorithm can be expressed as in (1) and (2) where the $\Delta \mathrm{P}$ is the differential of power, $\Delta \mathrm{V}$ is the differential of voltage and $\mathrm{k}$ is the sample time respectively.

$$
\begin{aligned}
& \Delta \mathrm{P}=\mathrm{P}(\mathrm{k})-\mathrm{P}(\mathrm{k}-1) \\
& \Delta \mathrm{V}=\mathrm{V}(\mathrm{k})-\mathrm{V}(\mathrm{k}-1)
\end{aligned}
$$

The four membership functions consist of negative big (NB), negative small (NS), positive small (PS) and positive big (PB) as shown in Table 1 [22]. The five membership functions consist of negative (N), zero (ZE), positive small (PS), positive $(\mathrm{P})$ and positive big (PB) as shown in Table 2 [17]. While the seven membership functions consist of negative big (NB), negative (N), negative small (NS), zero (ZE), positive small (PS), positive (P) and positive big (PB) as shown in Table 3 [23].

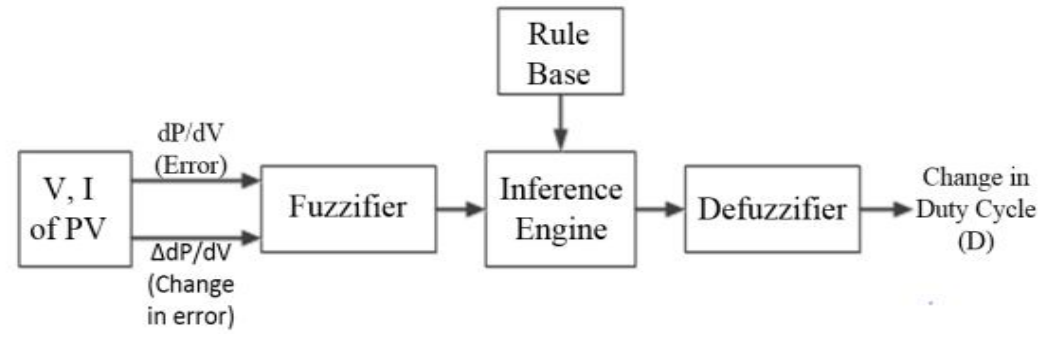

Figure 2: Basic structure of FLC in MPPT

Table 1: Adaptive P\&O-FLC MPPT 4 membership functions rule-base

\begin{tabular}{|c|c|c|c|c|}
\hline$\Delta \mathbf{P} \backslash \mathbf{V}$ & NB & NS & $\boldsymbol{P S}$ & $\boldsymbol{P B}$ \\
\hline NB & NB & NS & PS & PB \\
\hline NS & NB & NS & PS & PB \\
\hline PS & NB & NS & PS & PB \\
\hline PB & PB & PS & NS & NB \\
\hline
\end{tabular}

Table 2: Adaptive P\&O-FLC MPPT 5 membership functions rule-base

\begin{tabular}{|c|c|c|c|c|c|}
\hline$\Delta \boldsymbol{P} \backslash \boldsymbol{V}$ & $\boldsymbol{N}$ & $\boldsymbol{Z} \boldsymbol{E}$ & $\boldsymbol{P S}$ & $\boldsymbol{P}$ & $\boldsymbol{P B}$ \\
\hline $\mathbf{N}$ & $\mathrm{ZE}$ & $\mathrm{PS}$ & $\mathrm{P}$ & $\mathrm{PB}$ & $\mathrm{PB}$ \\
\hline $\mathbf{Z E}$ & $\mathrm{ZE}$ & $\mathrm{ZE}$ & $\mathrm{PS}$ & $\mathrm{P}$ & $\mathrm{PB}$ \\
\hline $\mathbf{P S}$ & $\mathrm{N}$ & $\mathrm{ZE}$ & $\mathrm{ZE}$ & $\mathrm{PS}$ & $\mathrm{P}$ \\
\hline $\mathbf{P}$ & $\mathrm{N}$ & $\mathrm{N}$ & $\mathrm{ZE}$ & $\mathrm{ZE}$ & $\mathrm{PS}$ \\
\hline $\mathbf{P B}$ & $\mathrm{N}$ & $\mathrm{N}$ & $\mathrm{N}$ & $\mathrm{ZE}$ & ZE \\
\hline
\end{tabular}


Table 3: Adaptive P\&O-FLC MPPT 7 membership functions rule-base

\begin{tabular}{|c|c|c|c|c|c|c|c|}
\hline$\Delta P \backslash \Delta V$ & $N B$ & $N$ & $N S$ & $Z E$ & $P S$ & $P$ & $P B$ \\
\hline NB & NB & $\mathrm{NB}$ & NB & $\mathrm{ZE}$ & PS & $\mathrm{P}$ & $\mathrm{PB}$ \\
\hline $\mathbf{N}$ & NB & $\mathrm{N}$ & $\mathrm{N}$ & $\mathrm{ZE}$ & PS & $\mathrm{P}$ & $\mathrm{PB}$ \\
\hline NS & $\mathrm{N}$ & $\mathrm{N}$ & $\mathrm{NS}$ & $\mathrm{ZE}$ & PS & PS & $P$ \\
\hline $\mathbf{Z E}$ & $\mathrm{ZE}$ & $\mathrm{ZE}$ & $\mathrm{ZE}$ & $\mathrm{ZE}$ & $\mathrm{ZE}$ & $\mathrm{ZE}$ & $\mathrm{ZE}$ \\
\hline PS & $\mathrm{P}$ & $\mathrm{P}$ & PS & $\mathrm{ZE}$ & NS & NS & $\mathrm{N}$ \\
\hline $\mathbf{P}$ & PB & $\mathrm{P}$ & $\mathrm{P}$ & $\mathrm{ZE}$ & $\mathrm{N}$ & $\mathrm{N}$ & $\mathrm{NB}$ \\
\hline
\end{tabular}

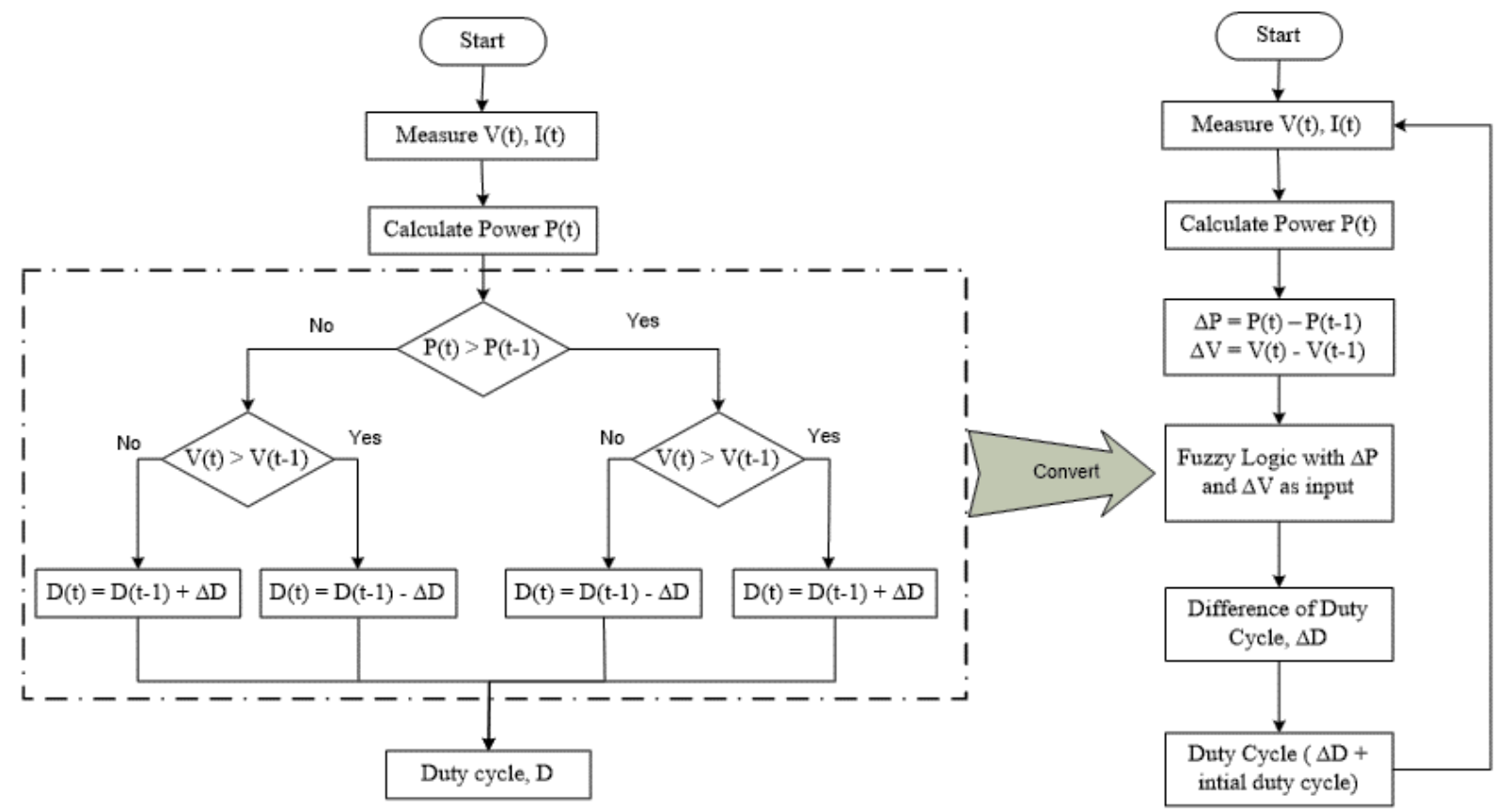

Figure 3: The flowchart of the Adaptive P\&O-FLC MPPT algorithm

\section{RESULT AND ANALYSIS}

The PV boost dc-dc converter was connected along with the load to form a complete standalone PV system. Kyocera Solar KD210GH-2PU PV module was used in this simulation which is the polycrystalline silicon and produces $210 \mathrm{~W}$ at $1000 \mathrm{~W} / \mathrm{m} 2$ with conversion efficiency of $16 \%, 26.6 \mathrm{~V}$ and 7.9 A. The parameters used for this PV module can be found in the Table 4.

The analysis of this simulation includes two tests which were under steady-state and dynamic operations. The results for the simulation have two parts which are the MPP performances and outputs of dc-dc converter. The parameters needed to be analyzed were the parameters of time response, overshoot, stability and MPP ratio. This simulation only focus on the changes of irradiance as temperature is fixed at $30^{\circ} \mathrm{C}$ because the changing in temperature effect is very slow compared to changing in irradiance and noise is considered in the simulation for testing the PV system to cope with the noise effect.
Table 4: Parameter of PV Module Kyocera Solar KD210GH-2PU

\begin{tabular}{|c|c|}
\hline Specifications & Value \\
\hline Maximum power $\left(P_{m g g}\right)$ & $210 \mathrm{~W}$ \\
\hline Maximum Voltage $\left(V_{m g}\right)$ & $22.6 \mathrm{~V}$ \\
\hline Maximum current $\left(I_{m g}\right)$ & $7.9 \mathrm{~A}$ \\
\hline Open circuit voltage $\left(V_{o c}\right)$ & $33.2 \mathrm{~V}$ \\
\hline Short-circuit current $\left(I_{s c}\right)$ & $8.58 \mathrm{~A}$ \\
\hline Temperature coefficient of $V_{O C}$ & $-0.36 \% / K$ \\
\hline Temperature coefficient of $I_{S C}$ & $0.06 \% / K$ \\
\hline Coefficient of temperature at MPP & $-0.46^{\%} / K$ \\
\hline Normal operating temperature of the cell & $25^{\circ} \mathrm{C}$ \\
\hline
\end{tabular}

\subsection{Steady State operations}

All the MPPT algorithms were combined in a single simulation and were simulated at the same time in the steady-state test. Figure. 4 shows the output voltages for each MPPT algorithms with different irradiance values the irradiance of 200, 600 and $1000 \mathrm{~W} / \mathrm{m} 2$. Figure. 5 displays the time response in the steady state for each MPPT algorithms. In comparison with the conventional $\mathrm{P} \& \mathrm{O}$, the Adaptive P\&O-FLC MPPT algorithm shows an outstanding result of 
faster time response, more stable and lower overshoot. Table 5 shows the detailed analysis effect on the PV boost converter. The comparison between the membership functions of Adaptive P\&O-FLC MPPT algorithm displays that 5 membership functions has slightly fast time response than 7 membership functions and followed by 4 membership functions. 7 and 5 membership functions are more stable compared to 4 membership functions and Figure. 4 shows the 5 membership functions has the highest overshoot while 7 and 4 membership functions have the same overshoot. In Figure. 5 at $1000 \mathrm{~W} / \mathrm{m}^{2}, 4$ membership functions have highest overshoot followed by 7 and the least was the 5 membership functions.

In Figure. 6 shows under low irradiation, the $\mathrm{P} \& \mathrm{O}$ did not perform well and induces losses of energy in MPP. At the 200 $\mathrm{W} / \mathrm{m} 2$, the Adaptive P\&O-FLC MPPT algorithms performed faster response time compared to the P\&O MPPT algorithm. Meanwhile comparison between the Adaptive P\&O-FLC algorithm, it is shown that the 5 membership functions have the fastest time response followed by the 7 membership functions and 4 membership functions. Above $600 \mathrm{~W} / \mathrm{m}^{2}$, all the membership functions have the same time responses. Table 6 shows the detailed analysis for the each MPPT in MPP ratio.

Table 5: Comparison results for each MPPT converter's voltages

\begin{tabular}{|c|c|c|c|}
\hline MPPT algorithm & Overshoot $(\mathbf{V})$ & Time response (ms) & Stability \\
\hline P\&O & 14 & 120 & Not stable \\
\hline $\begin{array}{c}\text { Adaptive P\&O-FLC } \\
\text { 4x4 }\end{array}$ & 0.02 & 34.26 & $\begin{array}{l}\text { More } \\
\text { stable }\end{array}$ \\
\hline $\begin{array}{c}\text { Adaptive P\&O-FLC } \\
\text { 5x5 }\end{array}$ & 0.06 & 34.55 & $\begin{array}{l}\text { More } \\
\text { stable }\end{array}$ \\
\hline $\begin{array}{c}\text { Adaptive P\&O-FLC } \\
7 x 7\end{array}$ & 0.02 & 34.36 & $\begin{array}{l}\text { More } \\
\text { stable }\end{array}$ \\
\hline
\end{tabular}

Table 6: Comparison MPP results for each algorithms

\begin{tabular}{|c|c|c|c|}
\hline MPPT algorithms & Maximum power ratio (\%) & Time response (ms) & Stability \\
\hline P\&O & $73-98$ & 30 & Not stable \\
\hline $\begin{array}{c}\text { Adaptive P\&O-FLC } \\
\text { 4x4 }\end{array}$ & $91-99$ & 19.54 & $\begin{array}{c}\text { More } \\
\text { stable }\end{array}$ \\
\hline $\begin{array}{c}\text { Adaptive P\&O-FLC } \\
\text { 5x5 }\end{array}$ & $92-99$ & 18.75 & $\begin{array}{c}\text { More } \\
\text { Stable }\end{array}$ \\
\hline $\begin{array}{c}\text { Adaptive P\&O-FLC } \\
\text { 7x7 }\end{array}$ & $92-99$ & 19.73 & $\begin{array}{l}\text { More } \\
\text { stable }\end{array}$ \\
\hline
\end{tabular}

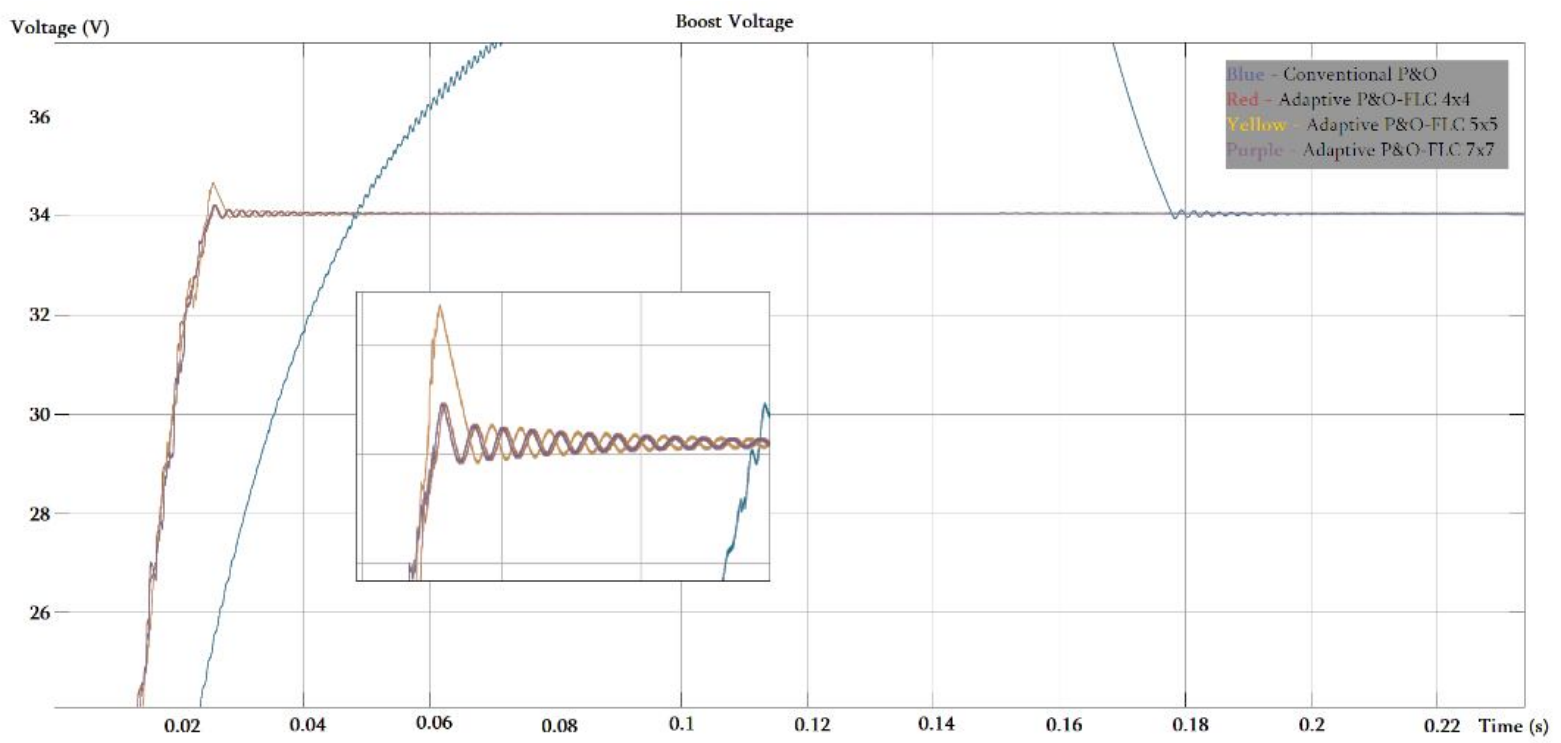

Figure 4: Boost dc-dc converter with different rapid changing irradiances 


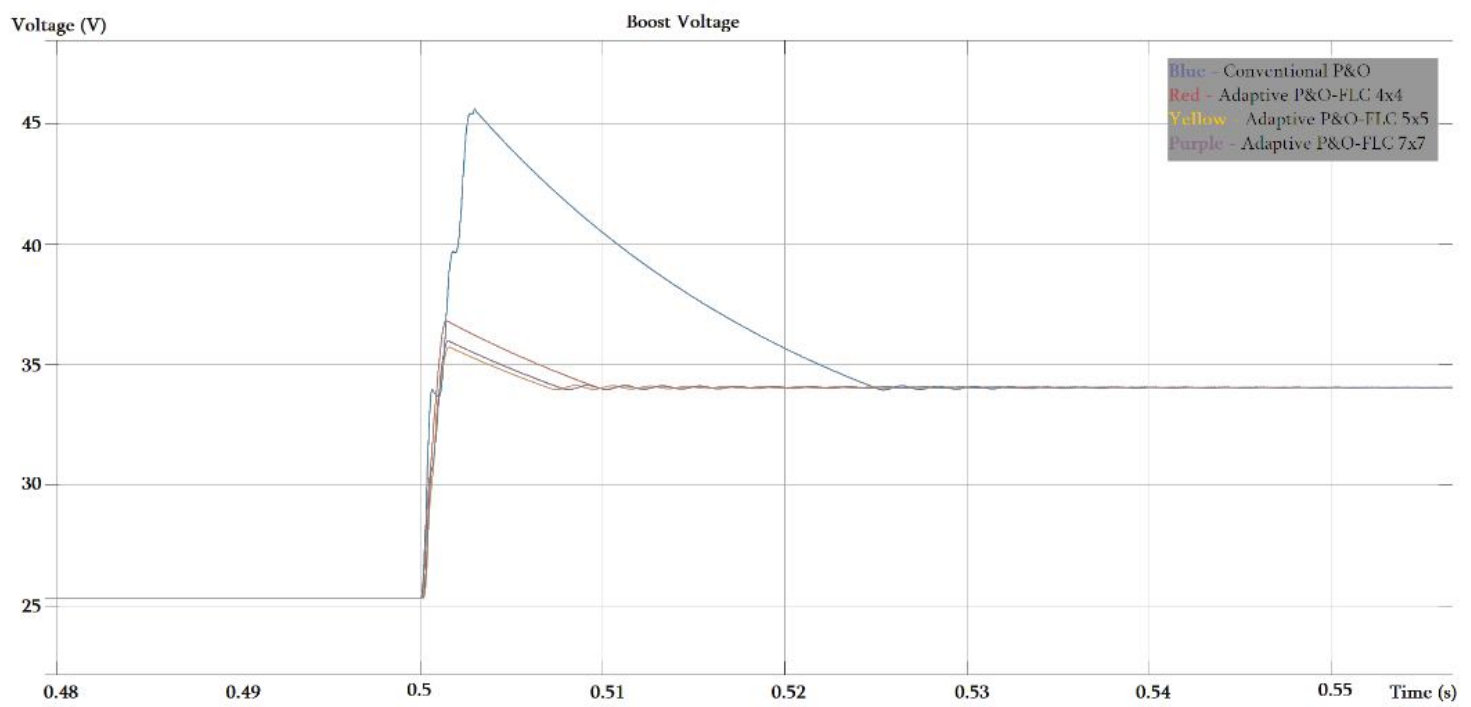

Figure 5: Boost dc-dc converter output voltage time response

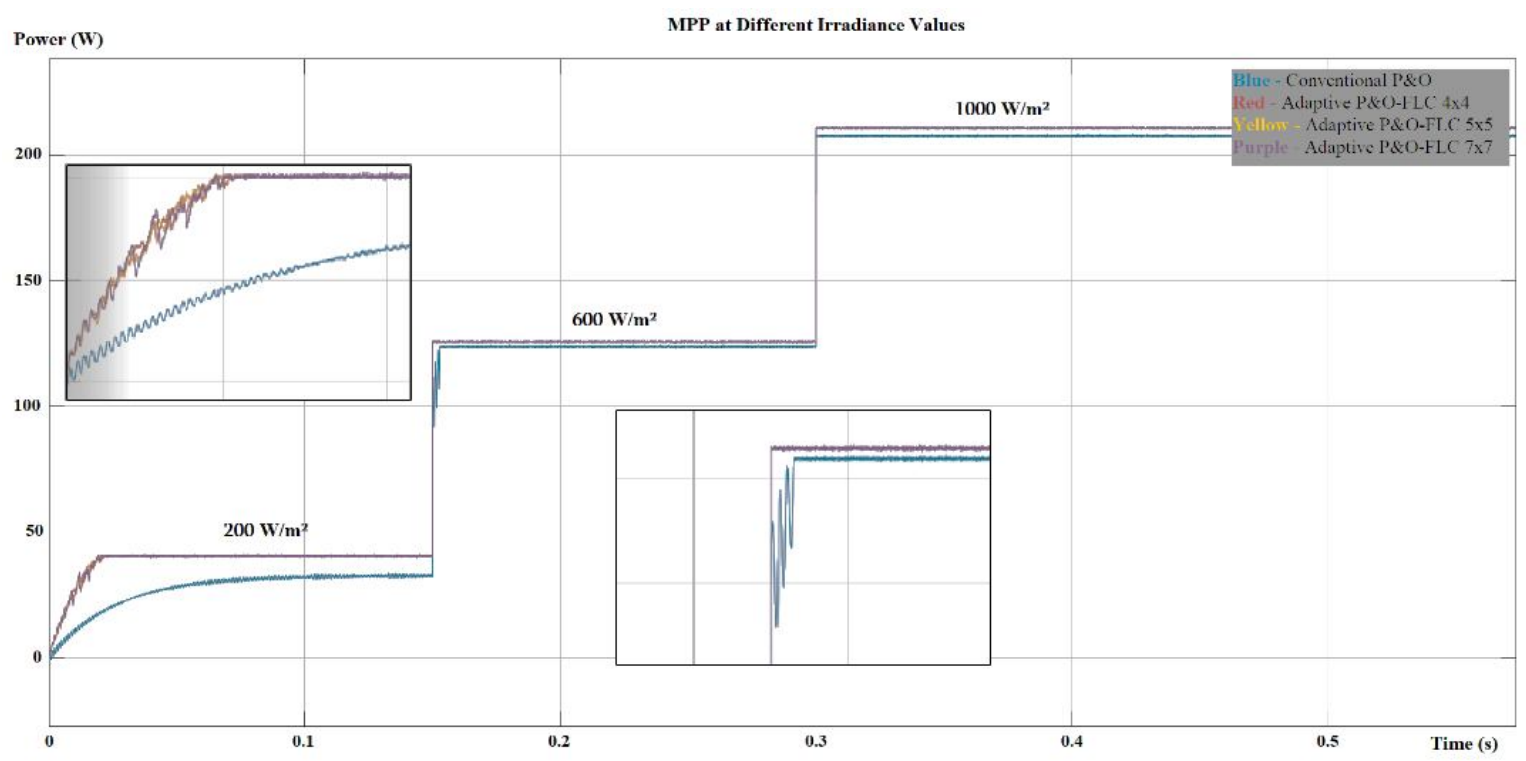

Figure 6: Performance of each algorithm towards MPP at different irradiance values

\subsection{Dynamic operations}

Simulation for dynamic test was done based on the European Standard (EN 50530) standard test of MPPT efficiency [24, 25]. The dynamic test of EN 50530 simulates the model under the changing of the rapid changes of the changing weather conditions. Essentially, the EN 50530 dynamic test involves in supplying irradiance with different ramp sequence (gradient) [14, 19]. The low-medium irradiance has the range of $100 \mathrm{~W} / \mathrm{m}^{2}$ to $500 \mathrm{~W} / \mathrm{m}^{2}$ with gradient scale of $0.5 \mathrm{~W} / \mathrm{m}^{2} / \mathrm{s}$ to $50 \mathrm{~W} / \mathrm{m}^{2} / \mathrm{s}$ which is shown in Figure. 7. The medium-high irradiance has the range of the $300 \mathrm{~W} / \mathrm{m}^{2}$ to $1000 \mathrm{~W} / \mathrm{m}^{2}$ with the gradient scale of $10 \mathrm{~W} / \mathrm{m}^{2} / \mathrm{s}$ to $100 \mathrm{~W} / \mathrm{m}^{2} / \mathrm{s}$ which is shown in Figure. 8 . While the start-up and shut down for low irradiance has the range of $10 \mathrm{~W} / \mathrm{m}^{2}$ to $100 \mathrm{~W} / \mathrm{m}^{2}$ with the gradient scale of $0.1 \mathrm{~W} / \mathrm{m}^{2} / \mathrm{s}$ which is shown in Figure. 9.
Figure. 7 shows the result at low-medium irradiance that clearly shows that all Adaptive P\&O-FLC MPPT algorithms have good performances. Meanwhile, P\&O MPPT shows the lowest performance in term MPP ratio, high overshoot and not stable where it also showed the lowest and worst performance of $62.07 \%$ of power losses in Table 9. Figure. 8 shows the dynamic performance at medium-high irradiance, all the MPPT algorithms shows a good performance in producing high MPP ratio, fast time response and stable results. The combined P\&O-FLC MPPT algorithms, however, also show the best dynamic performance results in contrast to the standard P\&O. At low irradiance as in the Figure 9 for test start-up and shut down test, the Adaptive P\&O-FLC MPPT algorithms also show the best results compared to the $\mathrm{P} \& \mathrm{O}$ algorithms, since the $\mathrm{P} \& \mathrm{O}$ shows high 
overshoot behavior causing energy losses. In addition, the comparison between the Adaptive P\&O-FLC MPPT algorithms also shows distinctive dynamic performance in low irradiance. The 7 membership functions show better performance in terms of accuracy in reaching MPP and highest MPP ratio than other two membership functions. However, 7 membership functions also show that it is not stable. The 4 membership functions give worst performance than other two membership functions which were lower MPP ratio and not stable. In comparison from all the membership functions in the Adaptive P\&O-FLC MPPT algorithms, the 5 membership functions produce most stable performance in dynamic. Table 7 until Table 9 show the dynamic MPP ratio for low-medium, medium-high, and start-up and shutdown at low irradiance respectively.

Table 7: MPP ratios for low-medium test

\begin{tabular}{|c|c|c|c|}
\hline $\begin{array}{l}\text { Gradient } \\
\left(\mathbf{W} / \mathbf{m}^{2} / \mathbf{s}\right)\end{array}$ & $\begin{array}{c}1 \mathrm{~W} / \mathrm{m}^{2} / \mathrm{s} \\
(\%)\end{array}$ & $\begin{array}{c}7 \mathrm{~W} / \mathrm{m}^{2} / \mathrm{s} \\
(\%)\end{array}$ & $\begin{array}{c}50 \mathrm{~W} / \mathrm{m}^{2} / \mathrm{s} \\
(\%)\end{array}$ \\
\hline $\mathrm{P} \& \mathrm{O}$ & 97.52 & 98.19 & 98.19 \\
\hline $\begin{array}{c}\text { Adaptive } \\
\text { P\&O-FLC 4x4 }\end{array}$ & 99.14 & 99.52 & 99.62 \\
\hline $\begin{array}{c}\text { Adaptive } \\
\text { P\&O-FLC 5x5 }\end{array}$ & 99.14 & 99.71 & 99.71 \\
\hline $\begin{array}{c}\text { Adaptive } \\
\text { P\&O-FLC 7x7 }\end{array}$ & 99.14 & 99.71 & 99.71 \\
\hline
\end{tabular}

Table 8: MPP ratios for medium-high test

\begin{tabular}{|c|c|c|c|}
\hline $\begin{array}{l}\text { Gradient } \\
\left(\mathrm{W} / \mathrm{m}^{2} / \mathrm{s}\right)\end{array}$ & $\begin{array}{c}20 \mathrm{~W} / \mathrm{m}^{2} / \mathrm{s} \\
(\%)\end{array}$ & $\begin{array}{c}50 \mathrm{~W} / \mathrm{m}^{2} / \mathrm{s} \\
(\%)\end{array}$ & $\begin{array}{c}100 \mathrm{~W} / \mathrm{m}^{2} / \mathrm{s} \\
(\%)\end{array}$ \\
\hline $\mathrm{P} \& \mathrm{O}$ & 98.76 & 98.76 & 98.86 \\
\hline $\begin{array}{c}\text { Adaptive } \\
\text { P\&O-FLC } 4 \times 4\end{array}$ & 100 & 100 & 100 \\
\hline $\begin{array}{c}\text { Adaptive } \\
\text { P\&O-FLC } 5 \times 5\end{array}$ & 100 & 100 & 100 \\
\hline $\begin{array}{c}\text { Adaptive } \\
\text { P\&O-FLC 7x7 }\end{array}$ & 100 & 100 & 100 \\
\hline
\end{tabular}

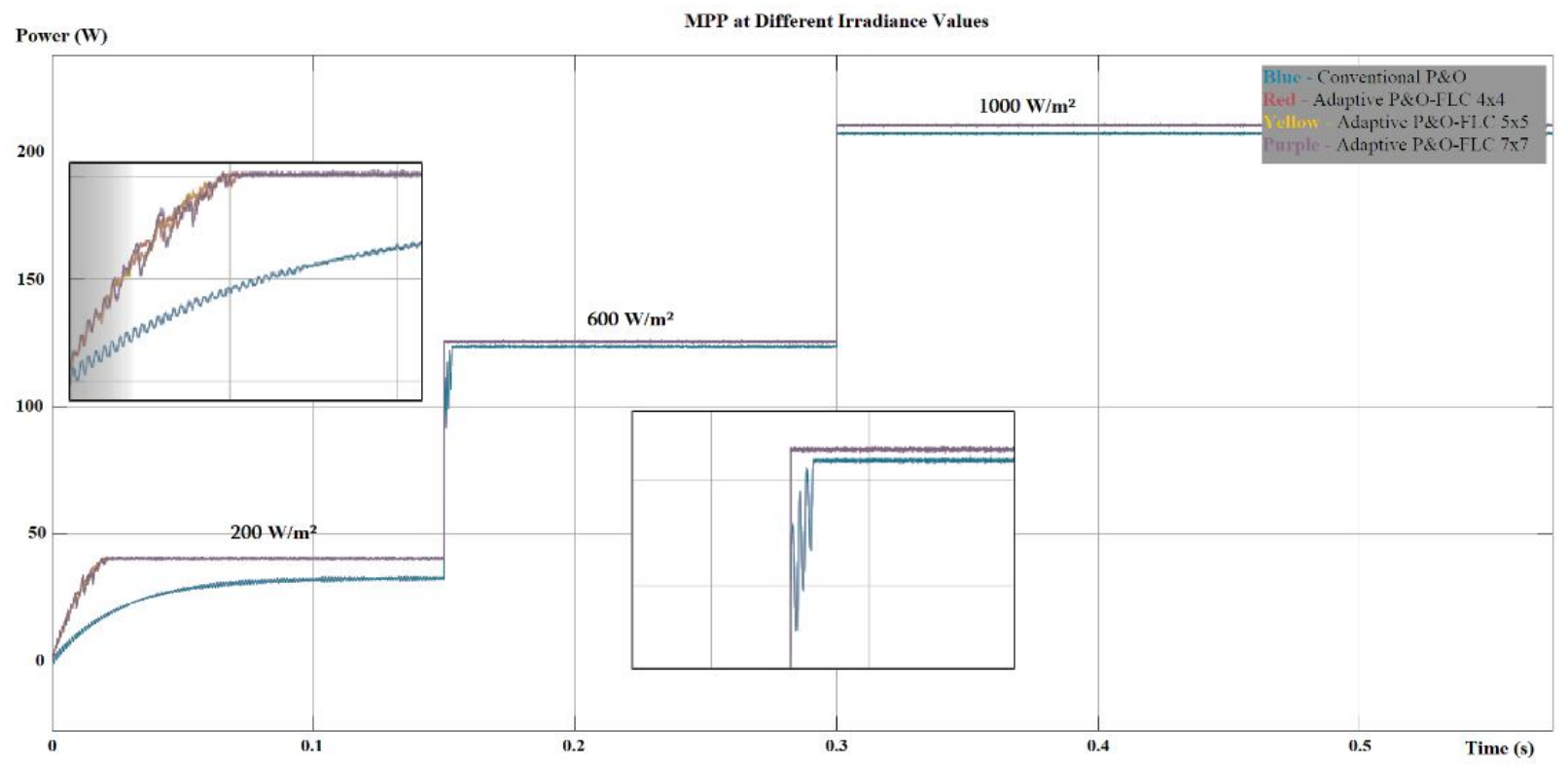

Figure 7: Dynamic performance for low-medium irradiance 


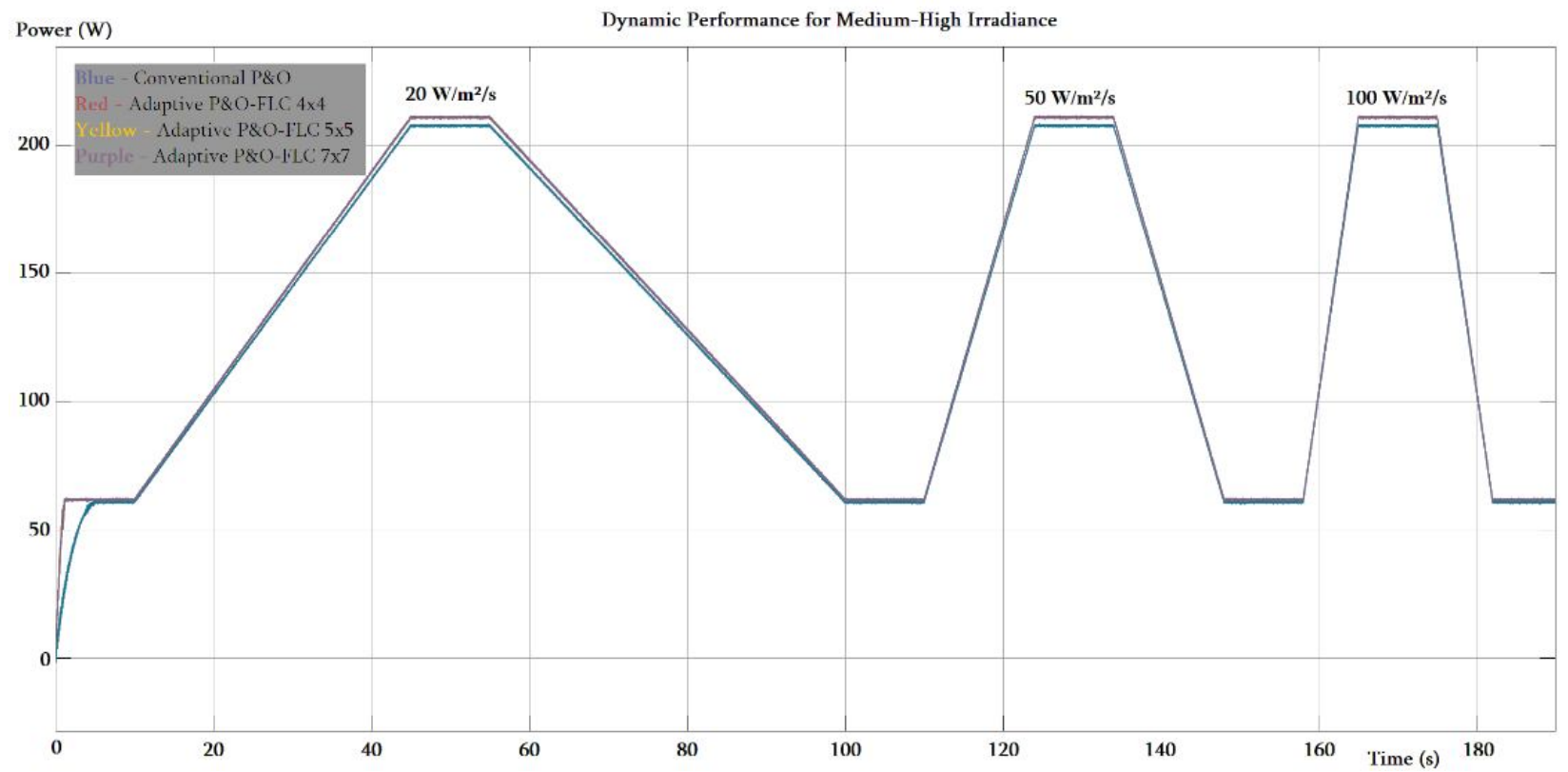

Figure 8: Dynamic performance for medium-high irradiance

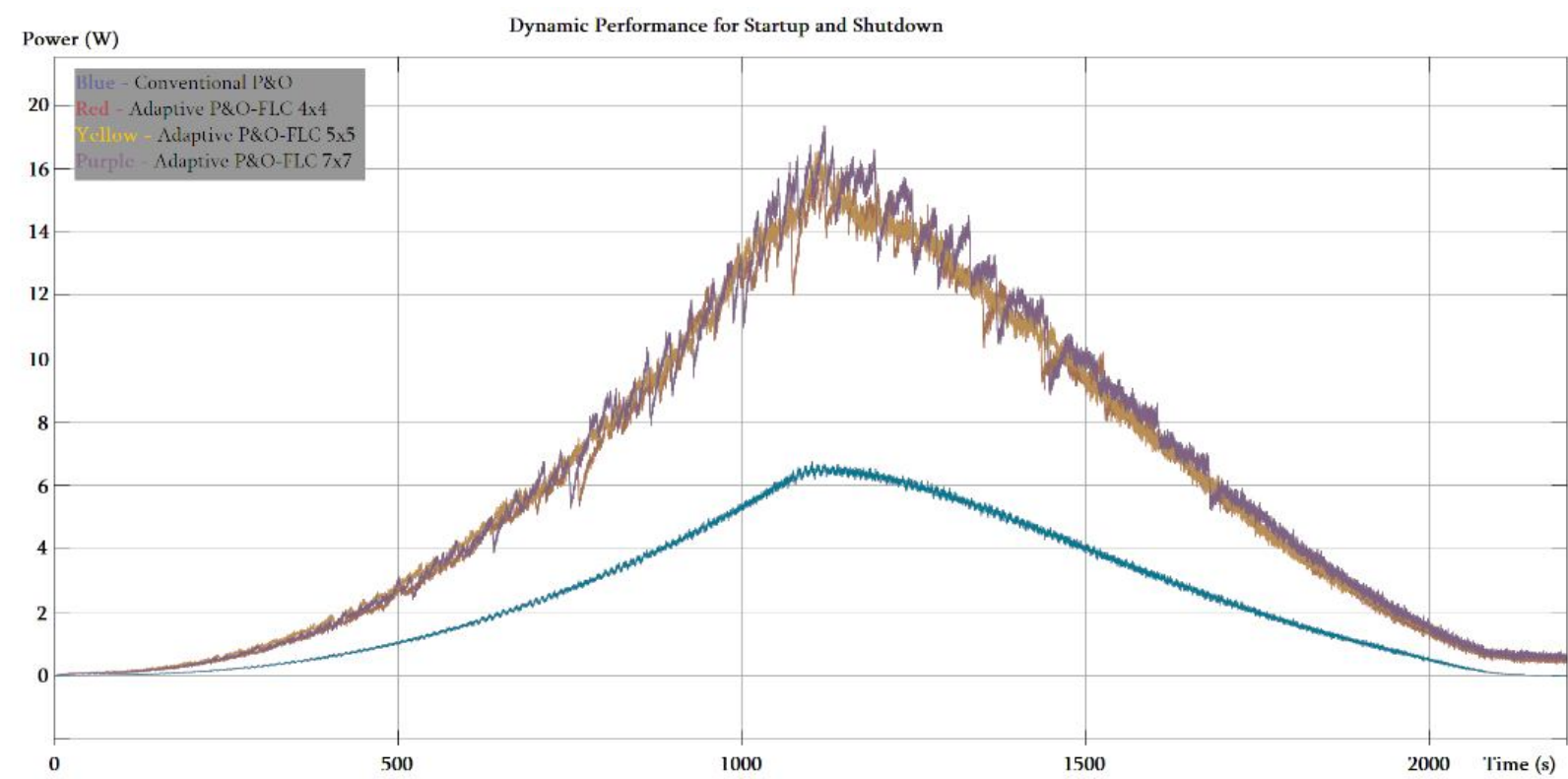

Figure 9: Dynamic performance for start-up and shutdown

Table 9: MPP ratios for start-up and shutdown test

\begin{tabular}{|c|c|}
\hline MPPT algorithms & MPP ratios (\%) \\
\hline P\&O & 98.76 \\
\hline $\begin{array}{c}\text { Adaptive P\&O-FLC } \\
4 \times 4\end{array}$ & 100 \\
\hline $\begin{array}{c}\text { Adaptive P\&O-FLC } \\
5 \times 5\end{array}$ & 100 \\
\hline $\begin{array}{c}\text { Adaptive P\&O-FLC } \\
7 \times 7\end{array}$ & 100 \\
\hline
\end{tabular}

\section{CONCLUSION}

This paper/work which involve the optimization of MPPT algorithm called Adaptive P\&O-FLC which compared with 3 different membership functions along with the Perturb and Observe MPPT algorithm act as base comparison to determine the best performance of MPPT. Those 3 membership functions were 4, 5 and 7 membership functions in the FLC. In the simulation, the assessments of the performance of each MPPT algorithms were carried out under two tests which are under steady-state and dynamic test. The steady-state test was carried out even though it is a common 
test for the MPPT as it used the step change of irradiance while the dynamic test is carried out based on the European Standard EN 50530. The combination of two MPPT algorithms which are $\mathrm{P} \& \mathrm{O}$ and FLC can create the Adaptive P\&O-FLC MPPT algorithm which the designed produced a better performance than the conventional P\&O MPPT algorithm. The findings also show that the Adaptive P\&O-FLC MPPT algorithm has better performance in these two tests of steady-state test and dynamic test. Overall comparison between conventional $\mathrm{P} \& \mathrm{O}$ and Adaptive P\&O-FLC MPPT in the simulation demonstrated, the Adaptive P\&O-FLC MPPT has the highest MPP ratio range of $91-100 \%$, it also has the best time response, overshoot and stable performance as compared with conventional P\&O.

Comparisons between different membership functions in the combined MPPT algorithm show that the 7 membership functions have the highest MPP ratio in the dynamic test. However, it still has higher overshoot, slower timer response and not stable compared to 5 membership functions which is only slightly lacks in MPP ratio. 4 membership functions have the lowest performance compared to the other membership functions. Thus, 7 and 5 membership functions have its own pros and cons in terms of its overall performances which both can be used as an MPPT that have better performance in PV system compared to the conventional MPPT.

\section{ACKNOWLEDGEMENT}

Research University Grant (GUP-2018-024) by Universiti Kebangsaan Malaysia.

\section{REFERENCES}

1. M.S. Ibbini, and A.H. Adawi. Analysis and design of a maximum power point tracker for a stand-alone photo voltaic system using simscape, International Journal of Advanced Trends in Computer Science and Engineering, vol. 8, no. 1, pp. 54-57, January-February 2019.

https://doi.org/10.30534/ijatcse/2019/09812019

2. F. Djaafar, B. Hadri, and G. Bachir. Optimization and Comparison between the Efficiency of InGaP and GaAs Single Solar Cells with and without a Window Layer, International Journal of Advanced Trends in Computer Science and Engineering, vol. 7, no. 1.4, pp. 61-66, July-August 2018.

https://doi.org/10.30534/ijatcse/2018/01742018

3. S.P. Zarikar, and M.R. Bachawad. Modelling of Grid Connected DC/AC Converterfor Photovoltaic Application. International Journal of Advanced Trends in Computer Science and Engineering, vol. 8, no. 1.4, pp. 404-407, 2019.

https://doi.org/10.30534/ijatcse/2019/6281.42019
4. G.P. Shirsat. Simulation of Grid Connected EV Charging Station with Renewable Energy Source. International Journal of Advanced Trends in Computer Science and Engineering, vol. 8, no. 4, pp. 415-419, 2019.

https://doi.org/10.30534/ijatcse/2019/6481.42019

5. V. Krishna, K. Seetharama Raju, M. Venkata Nagaraju, and K. Ravi Kumar. V-I curve and V-P curve of PV system with MPPT method, International Journal of Advanced Trends in Computer Science and Engineering, vol. 7, no. 6, pp. 152-154, November-December 2018. https://doi.org/10.30534/ijatcse/2018/18762018

6. H.M. Ammar, M. Azah and S. Hussain. A Nature-Inspired Optimization-Based Optimum Fuzzy Logic Photovoltaic Inverter Controller Utilizing an eZdsp F28335 Board, Energies, vol. 9, no. 3, pp. 120-152, Febuary 2016.

7. M. A. Hannan, A.G. Zamre, M. Azah, and M. Nasir Uddin. Real-time testing of a fuzzy-logic-controller-based grid-connected photovoltaic inverter system, IEEE transactions on Industry applications, vol. 51, no. 6, pp. 4775-4784, July 2015.

8. M. Yusop, A. Ramizi Mohamed, A. Afida, and M. Azah. Shapeable maximum-power point-tracking algorithm to improve the stability of the output behavior of a thermoelectric-solar Adaptive energy-harvesting system. Journal of the Association of Arab Universities for Basic and Applied Sciences, vol. 22, no. 1, pp. 1-8, February 2017. https://doi.org/10.1016/j.jaubas.2016.01.002

9. M.A. Younis, K. Tamer, N. Mushtaq, and A. Mohd Ariffin. An improved maximum power point tracking controller for PV systems using artificial neural network. Przeglad Elektrotechniczny, vol. 88, no. 3b, pp. 116-121, January 2012.

10. A.H. Mutlag, M. Azah, and S. Hussain. A comparative study of artificial intelligent-based maximum power point tracking for photovoltaic systems. IOP Conference Series: Earth and Environmental Science, vol. 32, no. 1, March 2016.

11. T. Tafticht, K. Agbossou, M. Doumbia, and A. Cheriti. An improved maximum power point tracking method for photovoltaic systems. Renewable energy, vol. 33, no. 7, pp. 1508-1516, July 2008.

12. B. Amrouche, M. Belhamel, and A. Guessoum. Artificial intelligence-based P\&O MPPT method for photovoltaic systems. Revue des Energies Renouvelables ICRESD-07 Tlemcen, pp. 11-16, September 2007.

13. R. Boukenoui, R. Bradai, A. Mellit, M. Ghanes, and H. Salhi. Comparative analysis of $\mathrm{P} \& O$, modified hill climbing-FLC, and Adaptive P\&O-FLC MPPTs for microgrid standalone $\mathbf{P V}$ system, international conference on renewable energy research and applications, pp. 1095-1099, November 2015. 
14. A. Haque. Maximum power point tracking (MPPT) scheme for solar photovoltaic system. Energy Technology \& Policy, vol. 1, no. 1, pp. 115-122, January 2014.

15. A. K. Abdelsalam, A. M. Massoud, S. Ahmed, and P. N. Enjeti. High-performance Adaptive perturb and observe MPPT technique for photovoltaic-based microgrids. IEEE Transactions on Power Electronics, vol. 26, no. 4, pp. 1010-1021, January 2011.

16. A. Mellit and S. A. Kalogirou. MPPT-based artificial intelligence techniques for photovoltaic systems and its implementation into field programmable gate array chips: Review of current status and future perspectives, Energy, vol. 70, pp. 1-21, Jun 2014. https://doi.org/10.1016/j.energy.2014.03.102

17. M. A. A. M. Zainuri, M. A. M. Radzi, A. C. Soh, and N. A. Rahim. Development of Adaptive perturb and observe-fuzzy control maximum power point tracking for photovoltaic boost dc-dc converter, IET Renewable Power Generation, vol. 8, no. 2, pp. 183-194, August 2013.

18. D. Verma, S. Nema, A. Shandilya, and S. K. Dash. Maximum power point tracking (MPPT) techniques: Recapitulation in solar photovoltaic systems. Renewable and Sustainable Energy Reviews, vol. 54, pp. 1018-1034, February 2016.

19. M. Blej and M. Azizi. Comparison of Mamdani-type and Sugeno-type fuzzy inference systems for fuzzy real time scheduling. International Journal of Applied Engineering Research, vol. 11, no. 22, pp. 11071-11075, 2016.

20. A. Kaur and A. Kaur. Comparison of mamdani-type and sugeno-type fuzzy inference systems for air conditioning system. International journal of soft computing and engineering, vol. 2, no. 2, pp. 323-325, 2012.

21. X. Li, H. Wen, Y. Hu, and L. Jiang. A novel beta parameter based fuzzy-logic controller for photovoltaic MPPT application. Renewable Energy, vol. 130, pp. 416-427, January 2019. https://doi.org/10.1016/j.renene.2018.06.071

22. S. D. Al-Majidi, M. F. Abbod, and H. S. Al-Raweshidy. A novel maximum power point tracking technique based on fuzzy logic for photovoltaic systems. International Journal of Hydrogen Energy, vol. 43, no. 31, pp. 14158-14171, August 2018.

23. O. Saban, N. Altin, and I. Sefa. Fuzzy logic based MPPT controller for high conversion ratio quadratic boost converter. International Journal of Hydrogen Energy, vol. 42, no. 28, pp. 17748-17759, July 2017.

24. R. Bründlinger, N. Henze, H. Häberlin, B. Burger, A. Bergmann, and F. Baumgartner. prEN 50530-The new European standard for performance characterization of PV inverters. EU PV Conferences, September 2009.

25. K. Ishaque, Z. Salam, and G. Lauss. The performance of perturb and observe and incremental conductance maximum power point tracking method under dynamic weather conditions. Applied Energy, vol. 119, pp. 228-236, April 2014.

https://doi.org/10.1016/j.apenergy.2013.12.054 